\title{
Entre o épico e o paródico: procesos de liberación nacional en La saga/fuga de $J$. B. de Gonzalo Torrente Ballester
}

\author{
Pablo Pesado Rodríguez ${ }^{1}$
}

Recibido: 14 de xuño de 2019 / Aceptado: 19 de xaneiro de 2020

Resumo. Gonzalo Torrente Ballester (1910-1999) é, sen dúbida, un dos máis importantes novelistas da literatura española da segunda metade do pasado século. A conquista desa posición canónica a partir dos anos 70 está directamente relacionada coa boa recepción, tanto por parte da crítica como por parte do público, da que gozou a súa novela La saga/ fuga de J. B., publicada en 1972. É tamén a partir dese momento que o autor se achegará á cultura galega e que comezará a participar dos seus debates intelectuais e políticos. Con este contributo pretendemos deitar luz sobre as estratexias que Torrente desenvolveu para conseguir ocupar posicións relevantes en dous sistemas -o galego e o español-sucados por un conflito nacional. Analizaremos con ese fin o papel que historia e historiadores xogan en La saga/fuga de J. B., prestando particular atención aos distintos procesos de liberación nacional que constitúen a súa trama. Intentaremos así dar unha nova lectura ao texto que o comprenda non só como un artefacto lúdico, senón tamén como un texto de compromiso político.

Palabras chave: novela histórica; alegoría nacional; autodeterminación; construción nacional; Torrente Ballester.

\section{[es] Entre lo épico y lo paródico: procesos de liberación nacional en La saga/fuga de J. B. de Gonzalo Torrente Ballester}

Resumen. Gonzalo Torrente Ballester (1910-1999) es, sin duda, uno de los más importantes novelistas de la literatura española de la segunda mitad del pasado siglo. La conquista de esa posición canónica está directamente relacionada con la buena recepción, tanto por parte de la crítica como por parte del público, de la que gozó su novela La saga/fuga de J. B., publicada en 1972. Es también a partir de ese momento que el autor se aproximará a la cultura gallega y que comenzará a participar de sus debates intelectuales y políticos. Con esta contribución pretendemos arrojar luz sobre las estrategias que Torrente desarrolló para conseguir ocupar posiciones relevantes en dos sistemas -el gallego y el español- atravesados por un conflicto nacional. Analizaremos con ese fin el papel que historia e historiadores juegan en La saga/fuga de J. B., prestando particular atención a los distintos procesos de liberación nacional que constituyen su trama. Intentaremos así dar una nueva lectura al texto que lo comprenda non solo como un artefacto lúdico, sino también como un texto de compromiso político.

Palabras clave: novela histórica; alegoría nacional; autodeterminación; construcción nacional; Torrente Ballester.

\section{[en] Between Epic and Parody: National Liberation Processes in Gonzalo Torrente Ballester's La saga/fuga de J. B.}

Abstract. Gonzalo Torrente Ballester (1910-1999) is, without any doubt, one of the most important spanish novelists of the second half of the past century. The achievement of this canonical position is in direct relation to the good reception of his novel La saga/fuga de J. B. (1972), which was acclaimed by the critic and public. Also, it is at this moment when the author decided to get close to the Galician culture and to participate in its intellectual and political debates. With this contribution we aim at enlightening the strategies that Torrente has developed in order to achieve key positions in two systems crossed by a national conflict: the Galician and the Spanish ones. For this purpose, we will analyse the role that history and historians plays in La saga/fuga de $J$. B. while paying special attention to the different national liberation

1 Universidade de Santiago de Compostela. Doutorando no programa de Estudos da Literatura e da Cultura da USC baixo a dirección do profesor Arturo Casas Vales. Membro do grupo de investigación GI-1371 Teoría da literatura e Literatura comparada.

Correo-e: pablo.pesado@rai.usc.es / pablopesado@gmail.com; https://orcid.org/0000-0002-9105-4113. 
processes represented in the novel. Our objective is to reread the text not only as a ludic artefact, but also as politically committed literature.

Keywords: Historical Novel; National Allegory; Self-Determination; Nation-Building; Torrente Ballester.

Sumario. 1. Introdución. 2. O lugar paródico e apócrifo da memoria galeguista. 3. Redención fronte a quen? Os imprecisos antagonistas de Castroforte del Baralla. 4. A posibilidade dunha lectura épica e dun horizonte político galego. 5. Conclusións. 6. Referencias bibliográficas.

Como citar: Pesado Rodríguez, P. (2020): "Entre o épico e o paródico: procesos de liberación nacional en La saga/ fuga de J. B. de Gonzalo Torrente Ballester", en Madrygal. Revista de Estudios Gallegos 23 Núm. Especial, pp. 267-283.

\section{Introdución}

A figura de Torrente Ballester ocupa un lugar particular nos sistemas literarios español e galego e nos seus respectivos discursos historiográficos ${ }^{2}$. Na historia literaria española, o autor adoita ser considerado como parte da chamada 'nova novela', 'novela intelectual' ou 'década experimental'. O seu proxecto literario ocupa no interior destes conxuntos unha posición un tanto heterodoxa, posto que foi lido como un intento de recuperación da narratividade fronte a un panorama excesivamente centrado na reflexión metalingüística ${ }^{3}$. Con frecuencia tendeuse a explicar esta característica da poética torrentina en virtude dun hipotético substrato cultural -cando non étnico- galego; comprendendo a presenza de elementos máxicos e humorísticos como derivados daquel. Segundo esta interpretación, o autor faría parte dun subsistema galego en castelán situado dentro dun sistema español máis largo, xunto a escritores como Pardo Bazán, Valle-Inclán, Álvaro Cunqueiro ou Elena Quiroga. Algúns dos trazos que definirían este subsistema, sempre entendido como heterónomo, serían o uso de elementos lingüísticos, espazos simbólicos e discursos culturais galegos. Por discutíbel que poida ser esta visión da traxectoria de Torrente, tanto desde a focaxe da análise cultural como desde a estritamente historiográfica, o certo é que foi rendíbel na altura na que o autor accedeu ao canon español -fundamentalmente no período entre 1970 e 1990 - e, cunha incidencia cada vez menor, aínda o segue a ser nos nosos días.

Se abrirmos o enfoque e incorporarmos a posición de Torrente no sistema literario galego, ambigua e mesmo polémica, o paralelo con aqueles escritores comeza a achar dificultades de magnitude non desprezábel. Como Valle-Inclán, é certo, Torrente comezou a súa andaina intelectual no cadro do galeguismo intelectual e político. Compañeiro de Alvaro Cunqueiro, Celso Emilio Ferreiro e Ricardo Carvalho Calero -entre moitos outros- nas Mocedades Galeguistas, pasa non obstante a se integrar após o golpe de Estado na falanxe universitaria. É así como comeza a súa carreira literaria -sempre en castelán- e tamén o seu papel como intelectual orgánico no primeiro franquismo ${ }^{4}$. Conforme vai devalando a ditadura, porén, Torrente irase afastando do réxime e comezará a estreitar vínculos con axentes da cultura galega dotados de gran capital simbólico e poder institucional. Moi preto do Grupo Galaxia orixinal, varios de cuxos membros lle eran vellos coñecidos, mais tamén en contacto coas novas xeracións, ocupará unha posición dentro do campo cultural que comeza a se institucionalizar. A diferenza de, por exemplo, o caso de Valle-Inclán, o camiño do escritor ferrolán foi de ida mais tamén de volta.

Esta posición difícil desde un punto de vista sistémico foi conscientemente cultivada por

2 De aquí en adiante empregaremos sistema literario no sentido específico que se lle outorga ao concepto no cadro das distintas teorías sistémicas aplicadas ao fenómeno literario e, nomeadamente, na 'teoría de polisistemas'. Véxase a este respecto, por exemplo, Even-Zohar 1990. Non ten aquí un sentido equivalente, polo tanto, ao de conceptos como literatura nacional ou historia literaria, aos que nos referiremos sempre mediante esas mesmas denominacións ou outras explicitamente relacionadas como discurso historiográfico, empregada xa nesta primeira liña do texto. Tamén botaremos man ocasionalmente de ferramentas propias da socioloxía dos campos de Pierre Bourdieu -nomeadamente toma de posición, capital e espazo dos posíbeis (Bourdieu 2000)- cando resultar de interese para tratarmos o obxecto de estudo.

3 Esta é, por exemplo, a postura desde a que Villanueva (1996) ten lido os contributos de Álvaro Cunqueiro á literatura española, dentro da cal sitúa a galega. Recentemente Guyard (2014: II) ten defendido unha opinión semellante con respecto a Torrente: "Frente al ya agotado realismo social y al experimentalismo que había deshumanizado a la novela, las novelas fantásticas de don Gonzalo recuperan el placer de contar historias sin caer en la trampa de un realismo ingenuo convencido de poder meter la realidad en las palabras".

4 Para unha mostra representativa das tomas de posición político-estéticas do primeiro Torrente, véxase, por exemplo, a escolma de poética e crítica teatral que ten reunido José Antonio Pérez-Bowie (Torrente 2009). 
Torrente no último tramo da súa vida, seguramente preocupado por non deixar pegada na posteridade dunha cultura galega para a que aparentemente se estaban a abrir, coa aprobación do Estatuto de Autonomía (1981) e Lei de normalización lingüística (1983), horizontes optimistas. O 'regreso' de Torrente manifestouse de distintas formas e, certamente, con diferentes obxectivos no volver do tempo. Desde a publicación de Los gozos y las sombras, Galiza converterase no seu escenario novelesco predilecto e tamén en obxecto dunha reflexión activa. Exemplos disto último poden ser o seu interese por repensar as relacións entre as culturas lusa e galega en Filomeno, a mi pesar ou intento de crear unha 'mitoloxía atlántica' en La sagal fuga de J. B. e Fragmentos de Apocalipsis 5 . O evoluír da súa traxectoria indica que Torrente probabelmente enxergou, tras intentar facer unha carreira literaria en Madrid cun éxito menor do desexado, que a galeguidade podía acabar xogando un importante papel como chave para acceder ao canon español. Mais tamén lle abría a posibilidade de xogar o papel na cultura galega ao que renunciara ao adherir ao bando sublevado. A obra coa que conseguiría o maior suceso nesa dupla estratexia sería La saga/fuga de J. B., texto que lle daría acceso aos máis importantes recoñecementos simbólicos das institucións españolas e que, paradoxalmente, tivo como principais continuadores os narradores da literatura galega do inicio da 'normalización'6.
A todas luces, pois, a súa estratexia acadou o suceso esperado; polo menos se a considerarmos dentro dos seus límites naturais: o 'criterio filolóxico' era inamovíbel, sendo que a literatura galega optara por se constituír nunha literatura nacional propia. Unha medida do seu éxito galego fornécenola a importancia de quen o reivindican. Así, por exemplo, na conversa coa que se inaugurou o anuario dedicado ao estudo da obra torrentina, La Tabla Redonda, importantes vultos da cultura de Galiza saían a defender o seu legado: Manuel Rivas, Víctor Freixanes ou Alfredo Conde entre outros. Nestes contextos, reivindicar Torrente adoitaba pasar por afirmar o carácter inequivocamente galego da súa produción literaria ${ }^{7}$. Tamén é indicativo do devandito éxito o feito de que a súa figura apareza dunha forma ou doutra en manuais de literatura galega. Xa na altura de 1975 inclúese o seu nome na Historia de la literatura gallega de Fernández del Riego ${ }^{8}$, recoñecemento simbólico co que tal vez se procuraba incentivar unha hipotética obra en galego de Torrente ${ }^{9}$. Unha decisión, por certo, non illada, pois após dous anos pasaba a formar parte do xurado que lle outorgaría a Xoguetes para un tempo prohibido o premio de novela co que a Editorial Galaxia conmemorara o seu XXV aniversario (Valls 2017: 378). Outro posíbel exemplo desta especie de lugar honorífico pode acharse en Vilavedra (2000), onde Torrente é traído ao debate como pedra de toque para sinalar os límites do criterio filolóxico:

5 Véxase, a este respecto, Mitos atlánticos en los mundos de Gonzalo Torrente Ballester (Cuba López 2017). A fortuna do termo mitoloxía atlántica, que se debe ao propio Torrente, mostra a que é unha das principais debilidades da recepción torrentina: a aceptación, ao noso xuízo pouco reflexiva, dos termos nos que o autor quixo que fosen lidas as súas obras. Así, a autora sinala que: "Esta etiqueta, que Torrente Ballester usa en lugar de las quizá más esperables mitos gallegos y/o mitos celtas, además de evitar las limitaciones que éstas implican, pone de manifiesto la oposición cultura atlántica / cultura mediterránea (...). Lejos de cualquier pretensión ideológica o política, en manos de Torrente lo atlántico tiene un sentido estrictamente literario, poético" (2017: 9). Esa aceptación dos propios termos torrentinos leva, como é patente neste caso, a unha confusión entre "pretensión" e "sentido" cando aplicadas ao potencial político do discurso narrativo. A preferencia do atlántico por diante do galego persegue, de certo, unha diminución da posíbel carga ideolóxica; precisamente por iso o "sentido" desta decisión é político.

6 Estámonos a referir ao conxunto de obras que, co obxectivo explícito de encheren baleiros repertoriais, tentaron achegar á literatura galega unha 'novela longa' ou 'gran novela galega'. Autores como Víctor F. Freixanes, Alfredo Conde ou Xosé Manuel Martínez Oca e, en xeral, aqueles que foron canonizados a través do Premio Blanco Amor de Novela Longa e cultivaron unha novela extensa, de temática histórica e decote enfeitada pola presenza de elementos máxicos. Véxase, sobre este tema, González-Millán 1994 e 1996 ou Vilavedra 2000. A centralidade dese proxecto na altura, así como a relativa capacidade de exportación ao contexto español que amosan os Premios de la Crítica recibidos por algúns dos autores nomeados, suxiren que a fórmula torrentina fornecera un modelo enormemente produtivo, aínda que nun alto grao dependente do sistema literario español.

Véxase Freixanes 2003 ou Alfredo Conde 2003.

8 "[P]ublicada en 1951, aínda que rematada en 1947, ten en cada período un apartado titulado «Escritores gallegos en castellano», excepto no capítulo «La nueva literatura». (...) [N]a publicada en 1975 ampliou e actualizou os coetáneos e introduciu, agora si, os escritores galegos en castelán onde cita a Camilo José Cela ou a Torrente Ballester" (Villanueva Gesteira 2015: 415).

9 Segundo Ponte Far 2019 o autor ferrolán comezara La saga/fuga de J. B. en galego movido pola insistencia de Ramón Piñeiro. 
A proxección como galegos, dun tempo a esta parte, de autores como Cela ou Torrente, non é casual. Porque a especificidade étnica dunha literatura depende máis da actitude dos diversos axentes que interveñen no proceso de producción [sic] e recepción literaria, de cómo estes se relacionan co mundo referenciado e de cómo asumen as súas responsabilidades discursivas e institucionais. (Vilavedra 2000: 12-13)

Aínda cando só for citado para xustificar certas exclusións do corpus da literatura galega, non debemos deixar pasar que esta é, de feito, tamén unha forma de inclusión. É, por tanto, unha proba da vitoria do modelo de intervención cultural que levou a cabo o último Torrente. A énfase que Vilavedra coloca sobre a noción de responsabilidade é, ao noso entender, a peza chave para comprendermos as lealdades que ten concitado a figura do escritor; moito máis do que elementos como a temática, a localización ou o hibridismo lingüístico cos que se ten negociado a galeguidade doutros autores galegos en castelán. Nunha intervención sonada, Torrente cargara publicamente contra a directora do Ateneo de Madrid por ter afirmado que 'non cría nas literaturas rexionais', levando a cabo unha acesa reivindicación da literatura en galego (Torrente 1987: 139-140). Nunha liña semellante, figuraría como asinante do manifesto de Realidade Galega en 1980. E, con menor relevancia política, mais na mesma dirección estratéxica, asinaba a introdución da tradución para o castelán de Ilustrísima de Carlos Casares ${ }^{10}$. Son tan só tres exemplos posíbeis desa "responsabilidade discursiva e institucional", talvez tamén dunha certa vontade de reparación ${ }^{11}$, que poida que explique a admiración que escritores como Alfredo Conde ou Carlos Casares lle profesaron.

Afirma Michael L. Martínez nunha entrada recente na bibliografía torrentina que o escritor foi, antes que nada, posuidor dun "habitus altamente produtivo" [Highly Generative Habitus] (Martínez 2018: 44), para alén de ser un "master strategist, defined as an agent who is adept at visualizing field positions with an eye towards maximizing dividends of capital" (Ibid.: 98). Esta visión dun Torrente experto na optimización das súas tomas de posición describe inmellorabelmente a fortuna dun escritor que soubo ocupar posturas tan flexíbeis como rendíbeis en dous sistemas literarios sucados por un conflito nacional. E que, convén lembralo, non escatimou esforzos en facer esquecer o seu pasado como escritor falanxista e reler a súa obra previa como unha decidida crítica ao poder político, unha 'desmitificación' da historia e das súas grandes figuras ${ }^{12}$.

La saga/fuga de $J$. B. publicouse no ano 1972, e con ela Torrente concitaría a aclamación crítica, o éxito de vendas e, sobre todo, ese lugar de convidado de pedra na literatura galega: o de configurador dun novo molde narrativo que serviría para artellar a 'novela longa' que caracterizou a década dos oitenta. Trátase, sen dúbida, dunha moi eficaz toma de posición. É necesario ter en conta as marcadas coordenadas históricas nas que o texto sae do prelo para comprendelo, ademais, como o texto de intervención política que é. Estámonos a referir a acontecementos como a fundación da UPG en 1963, as revoltas de Castrelo de Miño en 1966 e a morte do ditador en 1975. Este último feito levará ao inicio dun proceso constituínte en chave exclusivamente estatal; negando, polo tanto, a existencia de soberanías distintas á española que se puidesen fundar a través do exercicio do dereito de autodeterminación. Este cadro debe ser comprendido, ao noso ver, como algo máis do que un simple contexto. Trátase, nas palabras de Samartim de "um período de mudanças nas estruturas

10 Ese prólogo ten interese para comprobar cal era a opinión do autor sobre o estado actual das relacións sobre os sistemas literarios na Península Ibérica e sobre o seu horizonte desexado: “quiero (...) protestar (...) contra ese ghetto de ignorancia en que el español medio y muy buena parte de los que habitualmente leen, tienen y mantienen a los escritores en lenguas vernáculas. El hecho es irritante, y si (...) no es de creer que las cosas vayan a alcanzar un remedio inmediato, y que el único modo viable de conocer a uno de estos escritores sea el de traducirlo al castellano" (Torrente 1981: 9-10, apud Becerra 2017). Non é o único momento no que Torrente Ballester intercedeu por Casares no sistema literario español, talvez como contrapartida ao labor simétrico que por el facía Casares en Galiza. Así, Valls (2017: 379) lembra que, a dicir de Víctor García de la Concha, o autor de Vento ferido foi barallado como posíbel académico de número na RAE tras expresas e repetidas peticións de Torrente.

11 Loureiro $(2010,104)$ lembra que Torrente "nunca participó abiertamente, como lo hizo Ridruejo, en la oposición al franquismo, ni tampoco hizo un acto público de descargo de conciencia más o menos completo, como llevó a cabo Laín con la publicación de sus memorias".

12 Sobre a relectura da propia obra en termos de "desmitificación", o texto fundamental é o "Prólogo" á recompilación das súas obras teatrais (1982), pero tamén está presente nas súas entrevistas con Carmen Becerra (1990). 
de oportunidade politica" (2010: 15; itálico no orixinal): un momento no que moitas opcións políticas eran imaxinábeis malia pasaren a ficar, andado o tempo, aparentemente fóra do posíbel. La saga/fuga de J. B. ve a luz, por tanto, no contexto dun confronto por estabelecer as novas hexemonías e dotar aos posíbeis consensos futuros de límites claros que sinalen que debe ser admitido ou excluído do ámbito do político. E faino tematizando explicitamente procesos de liberación nacional no interior do Estado Español. Constitúese así nun caso con escasísimos equivalentes na literatura española contemporánea que, inexplicabelmente, continúa sen se considerar como unha entrada fundamental nese debate máis amplo.

Rastrexaremos o texto nunha dobre procura: por unha banda, da negociación textual que leva a cabo para conseguir ter distintos sentidos políticos en función do contexto de recepción; por outra, do resultado político global que puido ter nun momento no que o dereito á autodeterminación era reivindicado non só polo arco esquerdo da política galega, senón tamén da española. A pregunta fundamental, ao noso entender, é como un texto que encaixa co que Jameson (1993) chamara 'alegorías nacionais' puido, asemade, agochar esa condición de si mesmo en función do seu destinatario. A través dunha lectura atenta da novela tentaremos describir os mecanismos que desprega para inducir a distintos receptores a acharen nela distintos significados; facendo particular énfase nos procesos de liberación nacional que compoñen a súa trama. Na primeira sección analizaremos o papel que Torrente lles concede aos historiadores galeguistas e ao seu discurso historiográfico a través das ideas de parodia e caricatura. Revisaremos despois o funcionamento dos distintos antagonistas que a novela contempla na procura dun punto firme desde o cal edificarmos unha posíbel lectura emancipadora. Nun terceiro apartado prestaremos atención a algúns conceptos provenientes da filosofía da historia que o autor emprega para permitir unha visión épica, e xa non só paródica, dos protagonistas da novela. Concluiremos propondo unha interpretación de conxunto que sinale os compromisos políticos de La saga/ fuga de J. B., mais tamén as súas limitacións evidentes; pois trátase dun texto que visaba non só tomar unha posición en dous sistemas distintos, senón ademais colocar unha postura política activa sobre cal debía ser a súa relación e a das nacións que representaban.

\section{O lugar paródico e apócrifo da memoria galeguista}

Cuando se levantaron, riendo todavía, pero ya un poco serios, Castroforte parecía una nube lejana, donde quizás el Rey Artús empezase a proponer al pueblo la proclamación inmediata, definitiva, del Cantón Independiente, hasta que en el Reloj del Universo sonara la hora del regreso. (Torrente Ballester 1983: 585)

Así é como conclúe La saga/fuga de J. B.. É a descrición dunha posíbel proclamación de independencia que, no entanto, xa non poderá ser coñecida, posto que o narrador protagonista foxe do lugar onde até ese momento decorrera a historia. Trátase dun fragmento que resume ben os sentidos políticos da novela e as estratexias que emprega para atenualos. O que se está a representar -nun espazo tan decisivo desde un punto de vista hermenéutico como é a súa clausura- é de feito un proceso de autodeterminación ou, nas palabras da propia novela, "la liberación definitiva de Castroforte y su constitución en entidad política independiente" (1983: 92). Malia o carácter mesmo desafiante que poderían ter estas palabras abstraídas do resto do texto, a recepción contemporánea en España non pareceu atopar en La saga/fuga de $J$. B. ningún indicio de provocación. O receptor galego tampouco non viu nela unha novela de compromiso coa vangarda política da altura. A censura, que lle propuxo aplicar o silencio administrativo, non o fixo pola súa posíbel carga subversiva, senón polo seu carácter obsceno. Moi oportunamente, na reedición que a editorial Alianza vén de facer en 2019, o novo prologuista Andrés Barba abráiase da cegueira do censor perante a representación evidente dun conflito nacional ${ }^{13}$. Unha das posíbeis

13 "Sin duda una parte [do esquecemento da novela no canon literario español] tiene que ver con (...) cierta animadversión política. (...) tal vez se ha olvidado hasta qué punto los dilemas en torno a los cuales gira La saga/fuga siguen siendo hoy los que tenemos sobre la mesa (...) la identidad nacional, y no se me ocurren muchas obras donde se aprecia mejor hasta qué punto cualquier colectividad humana es una suma de gestos contradictorios, de luchas, invasiones, secretos y traiciones, complots, realidad y mito" (Barba 2019: 15). Dado que se trata dun paratexto dunha edición da propia obra para circulación española, o prologuista evita expresar abertamente o carácter concreto dese conflito ou a posición que adopta a novela. 
preguntas que poden levar a esclarecer o porqué desa 'cegueira', que perdurará despois na crítica torrentina, é a seguinte: quen está a iniciar un proceso de liberación e con respecto a que? Contestarmos esa pregunta precisa revisarmos primeiro o papel que xogan historia e historiadores nesta novela.

La saga/fuga de J. B. narra o sempiterno enfrontamento dunha provincia -a 'quinta provincia galega', Castroforte del Baralla, composta fundamentalmente pola vila do mesmo nome- co poder centralizador do Estado e coa cidade que é a súa valedora, Villasanta de la Estrella. Trátase dun conflito que se repite constantemente a través de tres mil anos de historia e cuxos protagonistas están condenados a reaparecer unha e outra vez a través dun ciclo de metempsicoses. Todo comeza sempre cunha invasión por parte da cidade veciña, sempre hai un home apelidado Bendaña que a encabeza e un representante da Igrexa que a lexitima, sempre xorde un heroe de iniciais J. B. para liderar a resistencia e todo acaba sempre coa derrota dos castrofortinos. Estes son os feitos centrais, mais non son os únicos que se repiten a través dos séculos. Así, por exemplo, aparece tamén a "Tabla Redonda", grupo de intelectuais e artistas reunidos arredor dunha revista do mesmo nome que velan pola conservación do patrimonio local e pola transmisión da súa historia. Nada a finais no século XIX, voltará unha e outra vez cando cheguen de novo as revolucións e as invasións profetizadas: no final da segunda república española e cara ao final da ditadura.

O modelo de historia cíclica serve ao autor para abarcar un amplo treito de tempo a través de pequenas calas. No canto de propor un relato histórico continuo, retrata distintas épocas partindo dos momentos exactos nos que se produce un estalido político. Estas, aliás, baséanse nalgúns dos grandes episodios da memoria galeguista, funcionando o relato histórico que propón Torrente como un pastiche do discurso historiográfico do protonacionalismo galego. Pastiche, e non resumo ou alegoría, porque aínda que o texto de partida é claro para o lector galego informado, a escolma privilexia personaxes e situacións tradicionalmente secundarios, mestura distintas xeracións de intelectuais, funde distintos persoeiros nun só e, en xeral, engade unha gran cantidade de material de propia colleita. O resultado ten sempre un aire de familia, mais ás veces o traballo sobre a fonte é tan grande que non permite unha total posta en paralelo. Estas dificultades son froito dunha coidadosa e consciente medición da ambigüidade, e teñen seguramente parte da culpa de que a novela teña sido lida máis como un exercicio de experimentación lúdica que como 'nova novela histórica' ou 'metaficción historiográfica' ${ }^{14}$.

A cumprida ollada que deita a novela sobre a historia galega parte dun presente case simultáneo ao do tempo da súa escritura no que as pegadas da Guerra Civil son evidentes mais parecen distantes. O pasado milenario é narrado pola súa personaxe principal (José Bastida), que accede a el a través de pescudas bibliográficas, transos mediúmnicos e soños. A través destes medios é capaz de habitar o interior dos seus antepasados e recuperar a súa memoria. No entanto, o maior peso narrativo recae, alén de na contemporaneidade, no período romántico no que se funda a primeira Tabla Redonda. A elección non é casual: preséntasenos unha xeración de intelectuais brillantes mais tamén excéntricos e pouco fiábeis que executan tarefas tan dispares como elaboraren unha Historia de Castroforte e unha teogonía (a Teocosmogonía), escribiren poesía lírica e antropoloxía hipotética. Pola combinación de intereses, non resulta difícil recoñecer unha mestura entre a Cova Céltica e unha Xeración Nós ou un Seminario de Estudos Galegos adiantados no tempo.

14 Para a primeira das dúas etiquetaxes véxase Hutcheon 1995 e 2004; para a segunda, por exemplo, Kohut 1997. O papel da historia na obra do autor ten concitado un enorme interese crítico; no entanto, non é frecuente ver adscrita a súa produción ás categorías citadas. Con excepcións, iso si, como Pérez 2010. Como indicamos, é probábel que a razón fundamental deste feito sexa o papel do máxico na súa etapa serodia. Mais poderíaselle engadir o descoñecemento por parte da crítica española da historia galega que opera como cadro presuposicional nas obras últimas de Torrente; o que provoca que episodios que demandan unha lectura historicista sexan lidos como material imaxinario. Este parece ser o caso, por exemplo, de Soldevila 1982, que introduce a distinción entre 'novela histórica' e 'novela de la historia'. A segunda, que aplica a La saga/fuga de J. B., caracterizaríase pola "confusión de niveles y períodos históricos" e por "una utilización de la historia como objeto novelesco" (1982: 134). Se ben eses trazos están presentes na novela torrentina, o certo é que tamén o están na mesma medida en boa parte das obras ás que se ten aplicado a etiquetaxe de nova novela histórica. 
Podemos tirar algúns exemplos sen pretensión de exhaustividade para estudarmos de que forma se estabelecen estas referencias ${ }^{15}$. Desta primeira xeración: Don Torcuato -líder absoluto e grande historiador desta primeira Tabla Redonda, mais tamén cabeza visíbel da proclamación da independencia- procede dunha mestura entre Manuel Murguía e Torcuato Ulloa; o vate Barrantes, poeta nacional de Castroforte, está a refundir a figura de Nicomedes Pastor Díaz. Os distintos J. B. e os momentos históricos nos que se enfrontan ao poder central adoitan representar momentos chave da historia galega: o arcebispo Bermúdez é unha clara transposición de Prisciliano e a morte do devandito Barrantes apunta cara a revolución de 1846. Amósase así unha fidelidade non só ao cadro referencial da historia galega senón, sobre todo, á súa estrutura temporal e narrativa. Menos clara é a escolla do almirante Ballantyne, reinterpretación do xeneral Moore, e do canónigo Balseyro, que representa a resistencia contra a Inquisición española. Ambas as dúas figuras defínense pola súa heteronomía con respecto ás canónicas no relato historiográfico español, mais os seus episodios -a Guerra do Francés e os procesos inquisitoriais- teñen, particularmente o último, unha menor incidencia no discurso nacional galego. Podemos conxecturar que, máis do que unha ruptura con respecto á lóxica xeral do proxecto metahistográfico de La saga/fuga, que debullaremos na sección 4, estes episodios algo disonantes amosan certas dúbidas á hora de o autor manexar as fontes e un esforzo por cubrir o inconveniente baleiro histórico dos séculos escuros ${ }^{16}$.

Moitas veces é difícil estabelecer sen risco as equivalencias exactas, por moito que se deixen intuír. Así, na xeración da Guerra Civil, non é imposíbel achar paralelismos con cabezaleiros do nacionalismo galego. Emilio Salgueiro, de quen o pouco que se ofrece é unha transcrición da súa mellor peza retórica, ten algo de Castelao no seu modelo: líder dun movemento político arredista e da Tabla Redonda do seu tempo, é condenado pola súa subversión e finalmente acaba exiliándose. A súa memoria só se conserva nunha magnífica peza oratoria que un papagaio memorizou e que a xente, clandestinamente, acode a escoitar á casa do seu propietario. A figura do traidor Jacinto Barallobre, que sorteou a morte e o exilio e agora leva unha vida de clausura e desprezo público, é igualmente suxerinte.

Máis interesante do que a identificación concreta de cada personaxe é o tratamento global que se lles concede. Estes materiais probabelmente demandarían un tratamento sublime no interior do imaxinario cultural galego; aquí aplícaselles, pola contra, un profundo rebaixamento paródico que actúa en dous estratos. Por unha banda, adxudícanselles defectos que van desde o físico -o nariz inzado de grans de Barrantes, a baixa estatura de Torcuato- até o moral -a desenfreada potencia sexual deste último, unha das maledicencias clásicas con que desprestixiaran Murguía. Trátase, pois, do modelo clásico da caricatura. Por outra banda, e xa no nivel narratolóxico, empréganse recursos metafictivos e un narrador protagonista non-confiábel para introducir incerteza e dúbida sobre a existencia real dos feitos narrados en xeral e daqueles coñecidos a través da xeración rexionalista en particular. A sátira e a incerteza narrativa combínanse nun plano máis amplo, por canto os defectos morais atanguen a personaxes que están a desenvolver un discurso historiográfico propio: o vicio moral trócase así en vicio epistemolóxico e a caricatura en aposta política.

Entre os diversos recursos dos que Torrente se serve para levar a cabo esta parodia despolitizadora das súas personaxes ocupa un lugar sobranceiro o uso que fai da sexualidade e da feminidade. En numerosas ocasións preséntanse os seus fins políticos como dependentes de intereses eróticos subxacentes ("Nuestra primera obligación, después del rescate de la Cibidá de manos ignorantes, y de la defensa y beneficio de las mozas locales (...)"; 1983: 126). Por exemplo, "La redacción" emprega un "De sociedad" en La Tabla Redonda -que, segundo Urza, referencia os primeiros Boletines de la Real Academia - para narrar as relacións sexuais do seu líder cunha prostituta (Ibid.: 123). O obxectivo claro é ofrecer sempre ao lector unha alternativa lúdica ás accións con maior carga

15 Para as equivalencias remitimos sempre a Urza 1991; no entanto, tentamos aquí complementar a súa análise.

16 Continuando nun plano puramente conxectural, é posíbel supor que o bo coñecemento do discurso historiográfico español por parte de Torrente, que fora profesor da materia, pode telo levado a comprender o relato histórico galego desde a estrutura interna desoutro. Podería dicirse que a escolma de grandes marcos da historia de Castroforte obedece non só aos momentos épicos galegos senón sobre todo a momentos escuros ou controversos españois. 
ideolóxica: ou ben a comprensión -en chave humorística- dos procesos revolucionarios como forma sublimada das paixóns venéreas ou ben como representación pública, solemne e masculina de asuntos domésticos, argalleiros e femininos. Sexualidade e muller ocupan unha función despolitizadora precisamente porque para Torrente fican fóra do político; nas conclusións reveremos este punto e a súa importancia na comprensión global da novela.

A énfase posta no período romántico en $L a$ saga/fuga de J. B. ten por certo unha sintomática xustificación no propio texto. Cando José Bastida, única persoa na cidade que coñece a súa historia - pois esta é sistematicamente ocultada polas autoridades españolas-, presenta aos que serán os seus compañeiros de Tabla Redonda unha "Disertación histórico-crítica" na que trata de sintetizala, afirma:

El doctor Amoedo [membro da primeira xeración] aseguraba que todo comenzó con la llegada de Argimiro el Efesio, pero eso sería tomar las cosas desde muy atrás (...). Porque, ¿quién nos demuestra que Argimiro el Efesio haya estado alguna vez en Castroforte (...)? Las verdades como piedras, a lo largo de dos mil años, pierden mucho de su fuerza de persuasión (...). Don Torcuato del Río [o "Rey Artús" da primeira Tabla Redonda], en cambio, se mostró siempre partidario de entender las cosas a partir de sí mismo como realidad indiscutible y palpable. (1983: 72)

Este argumento debullarase ao longo de dúas páxinas, e consiste en que o primeiro no tempo da historia debe de ser sempre o que é coñecido con maior certeza. Tal punto de vista pode parecer peregrino, mais encaixa co estilo narrativo da personaxe, sempre tendente á reticencia, á digresión, a cuestionar a credibilidade do seu propio discurso historiográfico e a introducir nel opinións subxectivas. Mais as páxinas posteriores apuntan tamén a un dobre sentido irónico presente nesas afirmacións. Pois a "Disertación" vai informando ao lector de que os membros da Tabla Redonda teñen grande afección por elaborar pastiches históricos (canards), que a lenda de J. B. ten visos de ter sido inventada e difundida para favorecer todo tipo de intereses persoais, e que os obxectos de culto que proban o pasado milenario da cidade son falsos. O seguinte fragmento pode exemplificar de que outras estratexias -ás veces realmente sutís- se serve o narrador para cuestionar a credibilidade das súas fontes:

como allí había estado [a Ara de Diana, peza fundamental do culto a J. B,], cerca de tres mil años antes, Argimiro el Efesio, y cuyo estado de conservación y limpieza era tan admirable como inexplicable: cosa de la calidad del mármol, seguramente. (Ibid.: 98)

Enténdese así, pois, que a decisión de José Bastida de comezar a historia pola xeración romántica non se debe a que sexa o episodio mellor documentado; é que o resto é certamente apócrifo, e polo tanto os seus inventores son a súa única orixe posíbel. Como en boa parte da súa obra, o autor ferrolán está aquí interesado en estudar o proceso de creación de mitos políticos e o uso da historia con fins interesados. O século XIX é un terreo fértil para este proxecto, pois é o momento no que os procesos de construción nacional se lexitiman mediante a 'imaxinación' (Anderson 1993) ou 'invención' (Hobsbawm 2000) do pasado do seu territorio. O principal alicerce teórico desta idea de 'desmitificación' é aquí Jacinto Bendaña, que volta á cidade para destruír a súa mitoloxía. É el quen nos dá a chave mestra de cal é o albo das críticas torrentinas ao insistir repetidamente (Torrente 1983: 364, por exemplo) en que o annus mirabilis da reinvención da historia é 1865: o ano no que tamén saíran do prelo os primeiros volumes das historias de Galiza de Murguía e Vicetto. Atopou Torrente no Rexurdimento galego e no nacionalismo de preguerra, así como nos seus vultos e no seu discurso historiográfico uns materiais enormemente produtivos por distintas razóns.

En primeiro lugar débese colocar como pano de fondo a alza do realismo máxico no campo literario mundial. Torrente foi de certo consciente de que contaba con activos culturais de enorme valor á hora de aproveitar os ventos favorábeis das tendencias contemporáneas. $\mathrm{O}$ realismo máxico como etnopoética baseábase na tese de que nunha sociedade na que conviven os mundos moderno e premoderno emerxe unha cosmovisión mixta caracterizada pola permeabilidade entre o fantástico e o real ${ }^{17}$. A tese de Galiza posuír esas condicións de emerxencia para o realismo máxico foi decote

17 Para unha panorámica da poética do realismo máxico latinoamericano, na que se conten distintas posturas con respecto ao peso do etnolóxico na súa formulación, véxanse, por exemplo: Durix 1998, Bowers 2004, González Echevarría 2004 ou Warnes 2009. 
difundida polo propio Torrente en entrevistas, artigos e prensa e escritos autobiográficos. Por unha banda, argüíndo como tamén fixera Cunqueiro que os galegos posuían unha suposta tendencia étnica cara ao xénero fantástico; por outra, que a súa convivencia na infancia entre o mundo rural e urbano, entre feudalismo e modernidade, levárao a posuír esa dobre ontoloxía literaria da que falaran os maxicorrealistas.

En segundo lugar, a escolla dun espazo nacional autónomo como protagonista colectivo -Castroforte del Baralla- e a concepción cíclica do devir histórico mostran que Torrente optou pola forma de realismo máxico máis orientada, como xa indicamos, cara ao modelo da 'alegoría nacional'. De novo, unha solución poética de gran fortuna no mercado literario da altura. Mais se esta alegoría aparece despoxada da súa compoñente política progresiva na proposta de La saga/fuga de $J$. B. é, ao noso xuízo, resultado da interferencia entre os dous sistemas literarios galego e español, que levan cara a un funcionamento diferente do modelo. A característica función de pedagoxía de masas que corresponde á 'alegoría nacional' precisa dunha identificación clara entre o lector ideal e a nación alegorizada. Se ben, como trataremos de demostrar, La saga/fuga de J. B. contempla un lector galego, o seu horizonte nacional é en gran medida español ${ }^{18}$. A función nacionalizadora a través dun relato épico subsiste, pero alterizada -vai ser representada como un Outro para un Mesmo-; a loita pola independencia política é presentada como caso peregrino, fabuloso e humorístico. Trátase, na nosa opinión, de dúas formas de exotización do galego ao atribuírlle, por unha banda, o devandito carácter máxico e pagán e ao presentar, por outra, a súa historia e os seus historiadores como un gabinete de curiosidades. O obxectivo desta visión exótica era tentar sobardar os límites habituais do subsistema literario español composto por autores galegos en castelán a través da importación de modelos internacionais puxantes que para o centro do sistema non estivesen dispoñíbeis ${ }^{19}$. Na cultura galega atopou as condicións de posibilidade para practicar o realismo máxico -isto é, unha comunidade comprendida como ancestral convivindo coa modernidade- e a alegoría nacional -é dicir, un proceso de nacionalización e confronto nacional actualmente en decurso. Esas precondicións eran inaccesíbeis para os escritores do centro do sistema español, cuxo relato nacional concedía escaso protagonismo á cultura campesiña e aos discursos etno-antropolóxicos. Vista no seu contexto, pois, La saga/fuga de J. B. visaba empregar unha concepción da heteronomía cultural de corte rexionalista -é dicir, aquela que comprende a literatura do subsistema a partir da diferenza cun centro cuxa poética é naturalizada e comprendida como grao cero neutro- para avantaxar asemade o canon central na súa autonomía estética.

Se contemplarmos, pois, tan só o até aquí aducido, o papel que se lle concede á historia política galega na obra de Torrente é claramente negativo: éo pola súa vertente satírica e pola súa intención exotizadora. Non é de estrañar que nas escasas ocasións nas que se ten feito referencia ao papel do conflito nacional galego-español na recepción académica de La saga/fuga de $J$. B. o resultado sexa desfavorábel para os primeiros. Así, Jiménez Hefferman afirma que ${ }^{20}$ :

Se trata, en rigor, de una adaptación -filtrada por los hallazgos del realismo mágico y de Valle-Inclán- de la sátira menipea clásica. (...)

18 Os lugares onde se deixa ver cal é o horizonte nacional do texto son innúmeros, pois este transparece a través das presuposicións, sobreentendidos e omisións que caracterizan o que Billig 1995 chamou "nacionalismo banal". Un exemplo posíbel pódese ver no seguinte fragmento: "la protección de la Cibidá y la conservación de sus calles, plazas, monumentos y demás cualidades que la hacían incomparable y única (según unos, en el mundo; según otros, en España; los más modestos, en Galicia, y ya estaba bien)" (Torrente 1983: 192). A distribución das tres entidades nunha estrutura de caixas chinesas ordenadas segundo criterios de universalidade/particularidade ou global/local revela o cadro axiolóxico subxacente e a posición que este lle concede a Galiza.

19 "The existence of a specific repertoire per se is not enough to ensure that a producer (or consumer) will make use of it. It must also be available, that is, being legitimately usable, not only accessible" (Even-Zohar 1990: 40).

20 Outra lectura posíbel que olle a parodia do nacionalismo galego como un aserto político forte é a de García 2011; ao meu xuízo, ilustrativa de até que punto a novela de Torrente permitiu tamén canalizar discursos de corte nacionalista español: "Los habitantes de Castroforte se afanan en crear mitos con los que producir un espacio propio, cayendo en la autosuficiencia que no permite ver que lo que aparentemente es ajeno también está incluido en la identidad propia. (...) A pesar de que la mitificación produzca ceguera (...) la novela en su conjunto insta a descubrir la impureza del origen, a desnaturalizar lo que se cree auténticamente propio y oriundo" (García 2011: 113). E acrecenta pouco despois: "Si los partidarios de la libertad se afanan a lo largo de mil años por reparar y variar el rumbo de la visión autoritaria que el poder tiránico quiere establecer, la novela muestra también las limitaciones de la reparación con las que se resisten quienes se oponen. Especialmente se señalan (...) los excesos de la imaginación desatada impulsada por la exaltación localista" (Ibid.: 115). 
La parodia del esencialismo nacionalista (aquí enmascarado en la oposicion celta-godo) es demoledora. El cuestionamiento de la eficacia analítica de la historia frente a la leyenda constante. (2004: 478; itálico noso)

Desde a outra banda do espectro político, Urza manterá nun traballo que foi pioneiro que "Según nuestra interpretación, el estudio de Bastida representa una parodia del regionalismo gallego del siglo XIX" (1991: 57) 21. Poláková, consciente da posibilidade dunha lectura en chave nacionalitaria, e nunha liña semellante á anterior, privilexia no entanto o seu carácter lúdico e "antidogmático" (2016: 67), aducindo as palabras do propio Torrente:

A La saga/fuga de J.B. le quieren dar una problemática trascendente (búsqueda de identidad y otras gaitas por el estilo) pero no hay ningún problema trascendente: hay algo de juego gratuito (aunque haya aspectos parciales serios e incluso en algunos momentos se llegue a la sátira moral y todo esto), pero los aspectos parciales no constituyen una unidad, no son un pivote sobre el que está montada la novela: la novela está montada sobre una actitud lúdica. (Becerra 1990: 240, apud Poláková 2016: 67)

Mais, se efectivamente o molde sobre o que se constrúe La saga/fuga de J. B. é o da sátira menipea e o seu obxecto son os desvaríos dos ideólogos dun "esencialismo nacionalista", como explicar a súa boa recepción no sistema literario galego? Unha posíbel chave atópase na cita anterior; que, no característico modo torrentino, trata de intervir no fluxo de retroalimentación que xeran as súas tomas de posición para mantelo dentro duns límites de seguridade hermenéutica: "hay algo de juego gratuito", mais tamén "aspectos parciales serios". Son estes últimos os que permiten comezarmos a enxergar unha resposta para a pregunta coa que comezabamos esta sección.

\section{Redención fronte a quen? Os imprecisos antagonistas de Castroforte del Baralla}

Malia as constantes evocacións á liberación e a independencia no libro, así como as súas combinatorias ("cantón independiente", "varón liber- tador") ou sinónimos parciais ("redención"), os motivos que poden levar ás distintas xeracións de castrofortinos a demandalas non son case nunca formulados como tales. Torrente ten a cautela de non permitir ás personaxes exporen os seus motivos fóra de sucintas declaracións programáticas que, na realidade, conteñen pouca información de valor:

aquellos asuntos para los que había sido fundada [la Tabla Redonda], es, a saber, la protección de la Cibidá y la conservación de sus calles, plazas, monumentos y demás cualidades que la hacían incomparable y única (según unos, en el mundo; según otros, en España; los más modestos, en Galicia, y ya estaba bien). (Torrente 1983: 192)

A partir de descricións como esta resulta difícil comprender como se chega da defensa do patrimonio municipal á proclamación da independencia. O texto case non ofrece pistas para trazar como, desde cando e fronte a que Castroforte precisa "protección". Os momentos nos que se produce a proclamación aparecen case sempre desconectados da causalidade dos seus respectivos fíos narrativos. Nas poucas reunións dos próceres castrofortinos ás que asistimos fálase de asuntos organizativos -como a decisión do nome do grupo-, culturais e sobre todo sexuais. Mais non se explícita, e nin sequera chega a transparecer, a vontade de levaren a cabo un proxecto emancipador no longo percorrido. En La saga/fuga de J. B. chegamos a coñecer polo miúdo a historia de Castroforte: as súas actividades económicas predilectas, os seus heterodoxos medievais, a súa prehistoria e o seu legendarium. E non obstante, nada chegamos a saber da natureza da súa secular ocupación e en que condicións se foi levando a cabo no volver do tempo.

A identificación máis clara prodúcese de esguello, cando se di que:

Don Torcuato creía en los J. B. pasados e incluso colaboró como el que más a su exaltación y gloria (...). Pero de ahí a participar en la esperanza de unas cuantas viejas y de un pueblo fácilmente sugestionable, y creer con ellos que J. B. había de regresar (...) y liberar a Castroforte de los godos, mediaba un abismo. (1983: 100)

21 De idéntica opinión é Pérez Gutiérrez, que ve nela a sátira dunha elite intelectual "jacobea, masónica, progresista, autonómica [!]" (2005: 15; énfase nosa). Martínez apunta igualmente que "the critical treatise he [Bastida] presents to the Round Table can be interpreted as a satirical version of Galicia's historical struggle for greater autonomy" (2018: 219). Di Sevilla Vallejo (2011: 49) que: "El conflicto (...) ahora se traslada a la identidad de una comunidad. No es que las luchas por el control de Castroforte y por la moral hayan desaparecido, pero lo más importante que está en juego es la misma existencia de Castroforte". 
Xa desde o principio da novela os "godos" ocupan un certo lugar antagonista, mais esta é a única pasaxe na que se indica abertamente que son os axentes desa dominación que baixo distintas feituras leva un milenio provocando a aparición de "varones libertadores". É dicir, trátase do único lugar onde se define con clareza cal é a verdadeira función política da Tabla Redonda. Non por casualidade, introdúcese no cadro dunha outra argumentación -sobre a utilidade como pedagoxía de masas da lenda apócrifa de J. B.- na que ocupa un lugar secundario e doadamente esquecíbel. "Godo" é, de feito, o nome que se lles dá en Castroforte aos españois, equivalencia sempre suxerida mais nunca afirmada; contraponse a "nativo" e, máis ocasionalmente, a "galio". Os godos acaparan os aparatos do estado en Castroforte: a policía, o concello, a administración, os servizos postais, a igrexa. Levan a cabo un programa de substitución da cultura e a historia local, que vai desde a destrución da súa memoria estatuaria á deturpación da toponimia (Castrofuerte por Castroforte ${ }^{22}$ ). Mais, sobre todo, a súa función é de control e vixilancia, posto que renden contas a unha secreta oficina central chamada "Ministerio de los Dispersos Centralizados". Como indica o seu nome, o seu obxectivo é previr as posíbeis contestacións ao proceso de unificación nacional.

De novo, a escolla do século XIX como principal escenario histórico ten unha importancia capital; mais agora nunha dirección política contraria. O que Torrente non nomea, mais que fica como coñecemento presuposicional preciso para comprender o que está a acontecer, é o proceso de nation-building do Estado Español ao longo do século xix e a drástica burocratización que implicou para todo o territorio sobre o que se reclamaba soberano. Posto que, como sinalaran Miroslav Hroch (1991) ou Ernst Gellner (2001), para deviren nacionais os Estados precisan capilarizar grandes extensións de terreo habitado sobre as cales o seu control fora imperfecto, delegado ou simplemente inexistente. Ese grande estrato burocrático será ocupado no caso galego case exclusivamente por funcionarios españois ${ }^{23}$. Un proceso que se adoita enxergar como continuador con respecto á substitución da aristocracia galega pola clase fidalga tras a chamada doma e castrazón.
Este conflito en particular é o que motiva ás tres xeracións de J. B. localizadas no longo presente novelesco; é dicir, aquelas que configuran o godo como "referente de oposición" (Beramendi 2007).

Os godos son a presenza antagonista que dá sentido á narración, mais Torrente procura atenuar o carácter político da dicotomía godos/nativos mediante varias estratexias. Estas complementan a dirección política que aplicara aos persoeiros galeguistas.

A primeira atinxe á combinatoria dos distintos referentes de oposición que ten Castroforte. Evítase polo xeral o uso tanto da palabra "godo" como de calquera perífrase que exprese un significado semellante en casos de confronto político entre dúas unidades territoriais. Exceptuándomos o caso xa aducido, os godos menciónanse con clareza en conflitos de orde municipal: así, os godos opóñense á recuperación da Tabla Redonda e do patrimonio local, son partidarios da imposición dunha sexualidade represiva e un catolicismo severo e velan pola persecución de toda tendencia revolucionaria ou secesionista (1983: 347). Esta nota de localidade ou municipalidade xoga como cortalume político, remitindo sempre ao contexto de retesías veciñais a quen atopar un contido máis subversivo. Deste xeito, adáptase a aquilo que o lector estea xa predisposto a ver, pedíndolle que ignore outros enunciados que a novela tamén contén. Pola contra, cando se quere falar dunha oposición política extramunicipal delégase o papel de Outro opositor en Villasanta de la Estrella, enclave godo no territorio co que Castroforte mantén unha eterna rivalidade. $\mathrm{O}$ procedemento é idéntico ao anterior: reducir mediante unha metonimia pouco clara -como veremos posteriormente- unha posíbel lectura alegórica e contrarrestar o peso do nacional con elementos de localismo. Ocasionalmente noméase ao opositor como "Poder Central" (Ibid.: 171) e unha soa vez como "Estado Central" (Ibid.: 130); sen dúbida as escollas con maior carga política. Nótese que se trata de usos que ignoran a compoñente nacional desa distribución de poder. O máis común para falar de procesos de liberación é, no entanto, a non mención do opositor ou do cadro histórico no que aqueles cobrarían un sentido. En conxunto, pois, a falta

\footnotetext{
22 Nótese que, inexplicabelmente, a denominación empregada por Torrente está tamén castelanizada, aínda que en menor grao: Castroforte del Baralla.

23 Véxase Monteagudo 1999.
} 
de clareza na identificación do adversario e a súa aparente multiplicidade -aparente porque, na realidade, fai parte dun só antagonista maior e nunca mencionado-contribúen a interpretar a liberación como carente dun dominador.

En segundo lugar, e en relación con este último punto, poderiamos falar dunha énfase na interpretación estrutural ou incluso actancial que o propio texto propón para si mesmo. Este contén numerosas reflexións postas en boca das personaxes sobre o seu carácter de 'funcións' nunha estrutura narrativa condenada a repetirse. Por exemplo, Bastida recomenda non asasinar o seu rival don Acisclo aducindo que, ao encarnar este unha función narrativa, sempre aparecerá outra persoa para executala nun relato que é superior aos seus axentes particulares (1983: 227-229). O texto fai patente que o esquema de dominación-subversión-derrota é incontornábel e superior a ese tipo de continxencias; é, antes que nada, unha estrutura narrativa predeterminada polo destino. Ábrese así a porta a unha interpretación do conflito no que prevalezan os aspectos estruturais fronte á concreción de cada presente e na que os factores políticos figuren como a mera aparencia dunha legalidade histórica máis profunda. $\mathrm{O}$ carácter particular da dominación nos séculos XIX e XX sería irrelevante, posto que se trata dunha opresión abstracta e transcendente encarnada en diversas feituras. Aínda cando o adversario for outro, a chegada dun imperio con superior capacidade militar sería inevitábel. Nesa liña apunta, por exemplo, o feito de que o primeiro destrutor de Castroforte sexa "Celso Emilio el Romano"; aínda que o resto de invasores sempre teñen a ver con España como suxeito histórico (a Inquisición, os patriotas fronte ao Castroforte afrancesado) prevalece a idea dunha dominación arquetípica acorde coa orixe mítica da cidade. A presenza de elementos máxicos - a cidade voadora, as lampreas que seguen o Santo Corpo Iluminado- contribúe a esta interpretación que, a pesar do emprego paródico da terminoloxía estruturalista, aproxima o texto á fábula.

A terceira, que confire sentido global ás anteriores, é o carácter metonímico da propia cidade de Castroforte, de Villasanta de la Estrella e dos "godos". O paradigma da 'alegoría nacional' pasa por cifrar nas traxectorias vitais dos seus protagonistas ou na caracterización dos seus espazos simbólicos contidos políticos que atinxen un proceso de nacionalización externo ao texto. Malia a preeminencia que posúe a alegoría na etiqueta do concepto non é a única relación semántica que este tipo de textos gardan co seu referente. En casos como o que estamos a analizar e, en xeral, nas ficcións que representan lugares situados no interior de comunidades políticas reais, o vínculo adoita ser metonímico: o destino do enclave, adoito imaxinario, garda a chave do destino da unidade maior que o contén. Enténdese pois ese espazo como microcosmos dun outro maior, do que sublima aquilo que é verdadeiramente fulcral para ofrecer unha verdade sobre a nación e a súa situación política. A diferenza da alegoría pura, a metonimia permite un alto grao de indeterminación con respecto a esa verdade nacional; precisamente porque a condición de parte do escenario novelesco introduce unha maior ou menor composibilidade co todo máis grande.

Este é, xustamente, o caso dos "godos". Como representantes do poder central en Castroforte, son tamén o seu equivalente semántico; e, no entanto, ao seren exclusivamente aqueles españois que viven na cidade, non permiten unha equivalencia total. Son só a parte dun conxunto máis amplo marcada, precisamente, pola súa alteridade, por seren "de fuera" (1983: 354). Idéntico caso acontece con Villasanta de la Estrella, mais tamén cos "nativos" ou "galios". O enfrontamento entre as dúas vilas funciona como versión microcósmica doutro conflito máis largo entre dúas entidades nacionais -e, tamén, entre dous bandos políticos: os afrancesados e os patriotas, os republicanos e os fascistas, etc.--, mais a pertenza de Villasanta á Galiza fai moi difícil enxergar o plano macrocósmico sen saltos de fe interpretativos. Non se trata, ao noso xuízo, dunha característica involuntaria nin secundaria do texto. $\mathrm{O}$ achegamento do autor á 'alegoría nacional' pasa tanto por cumprir cos seus trazos máis característicos como por agochar a chave textual; impedindo así a realización do seu obxectivo político clásico: o recoñecemento da dominación nacional nun reflexo idéntico e diverso asemade. Para obter de La saga/fuga de $J$. B. unha mensaxe semellante hai que esquecer ou sobreinterpretar deliberadamente; o cal non implica que esta non exista e, máis aínda, que non sexa a máis acaída desde unha focaxe hermenéutica.

Ora ben; se é certo que o autor introduce toda unha plétora de mecanismos para evitar a lectura alegórica que ela mesma demanda -ou, desde outra óptica, subtrae o asento hermenéutico que permitiría chegar a ela- hai unha importante diferenza entre o tratamento concedido aos heroes e aos opoñentes. En ningún momento se deitan dúbidas epistemolóxicas sobre a existencia plena dos últimos. As reiteradas acusacións 
de falsidade que recaen sobre os historiógrafos castrofortinos atinxen o seu relato histórico do pasado, mais non o adversario contra o que o elaboraron. Os estratos acumulados de historia apócrifa, mitos e lendas cos que as elites castrofortinas se opoñen ao poder central son historicamente dubidosos; mais o emprego deses medios ilícitos só ten sentido fronte a un inimigo real, cuxo control sobre o territorio se presupón en todo momento ilexítimo.

\section{A posibilidade dunha lectura épica e dun horizonte político galego}

É precisamente a partir deste paradoxo que podemos reconstruír a vertente épica de La saga/ fuga de J. B. e, seguindo coa comprensión do texto como un produto para dous receptores nacionais distintos, revermos aquilo que lle está a ofrecer á esfera pública galega. Torrente nega toda posibilidade de constituír un relato histórico independente e retrata os historiadores galegos como falsificadores; para compensar eses compromisos políticos, tenta converter o propio labor de "falsificación" histórica no centro argumental dunha posíbel épica galega.

Un lugar posíbel para entrarmos nesta dimensión do texto é a discusión que enfronta Josualdo Bendaña e José Bastida cara ao final da obra. Esta é sintomática, e tamén reveladora, dos seus compromisos epistemolóxicos e políticos. Aqueles que levan o apelido Bendaña están destinados a encabezar o exército que entre en Castroforte cando esta se rebele; Josualdo Bendaña, porén, non chega a Castroforte cun exército senón cunha ampla investigación histórica coa que pretende destruír o panteón de próceres locais. Na época contemporánea, pois, o confronto nacional xa non se libra no plano bélico senón no discursivo. Nas páxinas que van da 355 á 370, nunha entrevista concedida a $\mathrm{La} \mathrm{Voz} \mathrm{de} \mathrm{Castroforte} \mathrm{-xornal} \mathrm{afecto} \mathrm{a} \mathrm{La} \mathrm{Ta}$ bla Redonda- expón os erros e ausencias documentais e as invencións deliberadas nos que incorreron os historiadores locais do XIX até nada quedar en pé. Preséntase como unha figura de autoridade pola súa traxectoria académica nos Estados Unidos que vén exercer o papel de embaixador da desmitificación da historia. Como indicamos previamente, o termo desmitificación é o elemento nuclear da poética do último Torrente; por iso mesmo resulta inaudito velo empregado por un antagonista ao que o texto depara un tratamento fortemente negativo e incluso desprezativo. Así, incluso don Acisclo, principal opoñente da "Tabla Redonda" do presente confesa sentir por el un "profundo desprecio" (1983: 396). É a única personaxe que se refire sistematicamente a Castroforte como "Castrofuerte"; nun uso tan reiterado como excepcional que evidencia unha caracterización moral da personaxe. O tratamento paródico desta implica as mesmas estratexias que no caso dos protagonistas: ponse en dúbida a neutralidade da súa posición no debate historiográfico ao deberse ao "resentimiento" (Ibid.: 371). Á diferenza dos persoeiros galeguistas, non é posíbel contrapor a súa debilidade epistemolóxica á interpretación épica que imos trazar. Fronte aos membros da "Tabla Redonda", o uso partidista da historia é simplemente destrutivo; e a verdade que deita, estéril.

O retruque de Bastida (1983: 405-411) expresa aquí a posición epistemolóxica contraria: refuta o discurso de Bendaña con abonda evidencia documental que sabe falsa, porque é consciente do arbitrario de toda invención da tradición: "como sucede siempre (...) el que destruya el mito de los Jota Be, acabará ocupando su lugar" (Ibid.: 411). Tal e como se apunta despois, "[su] único inconveniente es su absoluta falsedad, aunque no espero que nadie (...) la descubra, de modo que viene a ser como si fuese verdadero" (Ibid.: 411). Non se trata, a pesar da aparencia, dunha proclama en prol do escepticismo historiográfico. Afirma un membro da última Tabla Redonda que a Historia de Castroforte de don Torcuato del Río é "una sarta de mentiras (...). Como todas las historias. Ésta, sin embargo, tiene una virtud: si es mala historia es, al menos, buena novela. Como novela la leía la gente, y así pudo creer lo que se decía" (Ibid.: 185-186). Este xuízo -que, lembremos, atinxe as seminais historias de Galiza de 1865- pode resultar nun primeiro momento un veredicto político severo e negativo, mais na particular axioloxía do escritor ferrolán supón unha toma-sempre cativa-de partido. Porque, para Torrente, a verdade histórica non procede da adecuación da narración aos feitos. Pola contra, toda narración histórica é arbitraria e inventiva, e a súa fortuna depende do grao no que revele unha verdade subxacente ${ }^{24}$. Por iso,

24 Véxase, a este respecto, Colmeiro 2004, na que se revé en profundidade a postura historiográfica do Torrente serodio a partir da novela La muerte del decano. Para unha perspectiva detallada da evolución do Torrente historiador, véxase Casas 2009. 
e sendo neste sentido aristotélico, acredita na novela como unha forma de perseguir idénticos fins aos da historiografía mediante distintas -superiores- ferramentas.

Esta discusión convida a revermos coas maiores cautelas a lectura desmitificadora desta obra; non porque esta non ocupe un lugar sobranceiro senón porque non é a súa chave alegórica última. Pola contra, está tamén no seu espírito -e ao noso xuízo con maior prevalencia- a defensa da creación de mitos como forma de resistencia vicaria perante un poder omnímodo. É pouco relevante o carácter real ou inventado dos marcos arredor dos cales as elites da cidade erixiron a súa narración nacional; dado que a dominación que os articula é real, a súa invención tamén é un acto de resistencia épico de seu. Esta si sería, por tanto, historizábel. Os protagonistas da novela teñen pechadas ás portas da verdade historiográfica e do heroísmo clásico, pero forman no devir das xeracións unha historia de resistencia. Esta está marcada polo pathos tráxico da derrota predestinada que, no entanto, non impide unha nova revolución. Desde esta perspectiva, a ollada satírica omnipresente na novela converte os seus heroes en encarnacións do eiron, a figura que na comedia clásica trae a verdade a pesar da súa aparencia indecorosa e merecente da burla.

Usando esta chave, creo que é posíbel acceder a aqueles "aspectos parciales serios" que o autor apuntara de esguello; vale dicir, esa verdade poética que á historia tradicional lle resulta inaccesíbel e que os heroes mitógrafos-novelistas atopan. En primeiro lugar, trátase dunha verdade concernente á súa estrutura metahistórica (White 1992). Torrente propón unha filosofía da historia para Galiza que faga da idea da derrota o seu núcleo organizador. Trátase, ao noso xuízo, dunha inversión daquela que propuxera Benito Vicetto, cuxa presenza aquí é moi acusada. Para o autor de Los hidalgos de Monforte a temporalidade de Galiza non se caracterizaría por seguir un percurso directo entre infancia prehistórica e madureza moderna guiado pola idea de progreso. Ao envés, é unha historia sucada por circularidades na que cada opresión pasada pode ser redimida por unha vitoria futura coa que non garda relación causal. O horizonte último é un futuro no que sexan compensadas todas as derrotas, revelándose finalmente como pasos indispensábeis para unha Galiza advida nación ${ }^{24}$. La saga/fuga de J. B. toma esta estrutura narrativa pero despóxaa do seu optimismo providencialista, facendo recaer a énfase no fracaso e non na vitoria. É, pois, a dominación a que vén condenar todo progreso.

Esta é unha visión pesimista do pasado proxectada cara ao futuro, pero para interpretarmos a súa polaridade política cómpre lembrar que precisa de dous elementos de corte emancipador para se artellar: a) un suxeito histórico de corte substancialista predestinado á rebelión e b) un inimigo destinado a vitoria pero carente de lexitimación. Isto foi o que lle quixo conceder ao receptor galego.

\section{Conclusións}

Ao longo deste artigo tentamos defender unha ollada emancipadora de La saga/fuga de J. B. que sinalase os seus compromisos políticos e os mecanismos activados para atenualos ou mesmo chegar a escurecelos en función do grao de coñecemento do material empregado. Con ese fin, aceptamos a comprensión do texto como fundamentalmente satírico, mais procuramos tamén sinalar os baleiros desa interpretación, centrada no tratamento dos heroes, cunha outra que analizase o funcionamento dos antagonistas. Tras unha ponderación das dúas vertentes da novela -épica e paródica-, o resultado amosa un predominio a nivel axiolóxico e epistemolóxico da primeira. $\mathrm{O}$ que non obsta, como vimos sinalando, que se trate dunha épica en gran medida despolitizada. $\mathrm{O}$ conxunto de escollas textuais que rastrexamos debe explicarse a través da idea da negociación; é dicir, como un intercambio no que as partes tratan de maximizar beneficios guiados por unha racionalidade económica. Torrente procurou, dentro das limitacións do seu espazo dos posíbeis -na formulación de Bourdieu (2002) - tirar os máximos réditos en dous campos distintos cunha soa toma de posición. $\mathrm{O}$ grao do compromiso finalmente adoptado polo autor correspóndese, probabelmente, co diagnóstico que o autor puido facer das forzas de cada unha das partes en conflito.

Para concluírmos, e recapitulando as teses que vimos propondo para interpretar esa toma de posición que foi La saga/fuga de J. B., quereriamos retomar o xa citado final da novela:

24 Para o que respecta á filosofía da historia interior á obra vicettiana, véxase Renales Cortés 1996. 
Cuando se levantaron, riendo todavía, pero ya un poco serios, Castroforte parecía una nube lejana, donde quizás el Rey Artús empezase a proponer al pueblo la proclamación inmediata, definitiva, del Cantón Independiente, hasta que en el Reloj del Universo sonara la hora del regreso.

Desde a perspectiva galega que tentamos defender, o parágrafo incide na estrutura de rebelión e derrota á que están condenados Castroforte e, como referente metonímico, Galiza. Mais, para sermos honestos, é preciso recoñecer que Torrente foi coidadoso á hora de dificultar esta lectura. Se, como afirmara Northop Frye, "[1]a alegoría genuina es un elemento estructural de la literatura: tiene que estar allí y no puede ser añadido por la sola interpretación crítica" (1997: 80), débese concluír que autor quixo evitar un funcionamento alegórico xenuíno. Isto, como vimos mantendo, non é óbice para atoparmos cumpridos patróns hermenéuticos cuxo camiño é interrompido pero que apuntan cara a ese albo. Non se trata dunha ausencia, senón dun borrado cuxa pegada fica. Algunhas destas, por certo, transitan tamén cara a direccións contrarias. Valla como exemplo disto a recensión que na altura lle facía Dionisio Ridruejo:

J. B. (...) ha descubierto el secreto de Castroforte: mientras la discordia se mantiene en ella, Castroforte está en el mundo. Cuando algún factor de atención muy intenso une a celtas y a godos, víctimas e inquisidores, mágicos y racionalistas, la ciudad, ensimismada, levita y se remonta a las nubes. La parábola es transparente. $(1997: 194)$

Na realidade, a parábola proposta dista de ser clara. A referencia aos celtas e godos fai referencia, sen dúbida, á unidade de España por riba dunhas diferenzas nacionais consideradas como étnicas, tribais ou feudais; no entanto, na propia novela non se fala en ningún punto de celtas, senón de "nativos" e, ocasionalmente, de "galios". "Víctimas e inquisidores" apunta, a todas luces, aos discursos sobre a "reconciliación", a "concordia" e a "convivencia" que se instalarían na esfera pública española arredor da fin da ditadura. Menos claro aínda, mais de enorme interese, é a oposición de "mágicos y racionalistas": talvez aluda aquí Ridurejo a ese carácter máxico propio da 'esencia' galega que Torrente tentara difundir como lexitimación etnopoética. A unión dos máxicos e realistas apuntaría, pois, á unificación nacional española. Nótese, en consecuencia, tanto a detección por parte de Ridruejo do peso que na novela tiña o conflito nacional como a distinta dirección que lle adxudica. Pouco importa que esta lectura teña pouco asento textual; o relevante é que foi posíbel e que, como vimos anteriormente, non foi isolada.

Como dicimos, calquera destas dúas lecturas é permitida e atopará en consecuencia un certo apoio no resto da novela. Non contribúe a unha maior claridade o contexto de emisión do simbólico final da novela: o narrador vén de fuxir coa muller que ama da cidade de Castroforte-que, alzándose no ceo, xa non lle permitirá nunca un retorno-e, no curso da fuga, sofre un arrebato de paixón e guíndase ao chan con ela. Sexa como for interpretada politicamente esa clausura, en definitiva, a mensaxe é debilitada por unha apelación superior ao goce da corporalidade e a renuncia ás tarefas políticas, historiográficas e literarias. A "nube lejana" apunta ao cativo dos procesos políticos abstractos en comparanza ao goce concreto do sensual. Este feito é simbolizado pola perda no medio da escapada dunha vella gramática de gran valor anticuario; a súa posesión máis valiosa e o único que tentara levar con el na fuxida. É precisamente ao decatarse desta perda que "Se encogió de hombros y, riendo, derribó a Julia en el césped" (1983: 585). O obxecto-libro representa aquí a cultura letrada mais, sobre todo, as súas funcións compensatorias e vicarias con respecto a un vitalismo viril reprimido. En resumo, un cortalume sensualista que marca con total clareza até onde pode chegar quen vise a súa compoñente "seria".

Falabamos ao principio da importancia de enxergar La saga/fuga de J. B. nese contexto de "mudanças nas estruturas de oportunidade política" que comezara a abrirse pouco antes da publicación da novela e que remataría pouco despois. Algunhas posibilidades tentativas xa se teñen debuxado aquí. Por unha banda, a exotización da cultura galega, o seu emprego como mercadoría fetichizada para calquera receptor estatal -tamén, por tanto, para o galego- e a desestimación da leximitidade dunha historia nacional propia. Por outra, unha proposta literaria que alumeou o camiño á primeira vaga de novela longa galega, un uso dos materiais galegos progresivo con respecto aos tradicionais dese hipotético subsistema e a afirmación do dereito á resistencia cultural. É difícil, se non imposíbel, dirimir cal foi a efectividade real do texto como obra política. Algunhas preguntas sobre o papel de Torrente fican sen resposta, pero continúan a demandar 
unha análise profunda. En que medida o último Torrente Ballester contribuíu a crear un certo imaxinario contemporáneo sobre a galeguidade e a difundilo entre clases medias lectoras dentro e fóra de Galiza? Que consecuencias políticas - probabelmente inmobilizadoras - tivo ese discurso no contexto da Galiza autonómica? Foi maior o seu contributo á aparición dunha novela longa de alento épico en galego ou, pola contra, á rexionalización dun hipotético subsistema galego en dependencia do sistema literario español -e mesmo do propio sistema galego? Nesa mesma liña, en que medida, como axente mediador dotado de cumprido poder simbólico, puido coadxuvar a converter o mercado español en referente de exportación privilexiado da literatura galega? Tales cuestións, que se apuntan aquí a título de exemplo, ultrapasan as posibilidades deste artigo. Queren facer notar todas, iso si, a conveniencia de revermos a importancia do papel mediador do autor e da súa obra entre dous sistemas literarios e dúas nacións en confronto. Un papel que, segundo todo parece indicar, debeu de ser relevante; mais que, por desgraza, continúa aínda pendente de esclarecemento.

\section{Referencias bibliográficas}

Anderson, Benedict (1993): Comunidades imaginadas. Reflexiones sobre el origen y la difusión del nacionalismo (trad. Eduardo L. Suárez). México D. F.: Fondo de Cultura Económica.

Barba, Andrés (2019): "Prólogo", en G. Torrente Ballester, La saga/fuga de J. B. Madrid: Alianza, pp. 7-16.

Becerra Suárez, Carmen (1990): Guardo la voz, cedo la palabra: conversaciones con Gonzalo Torrente Ballester. Barcelona: Anthropos.

- (2017): “A mestría no contar: Ilustrísima”, en L. Cochón, L. Alonso Girgado e L. Piñeiro Pais (eds.), Carlos Casares: homenaxe. De amicitia (Cadernos Ramón Piñeiro 37). Santiago de Compostela: Centro Ramón Piñeiro para a Investigación en Humanidades.

Beramendi, Justo (2007): De provincia a nación. Historia do galeguismo político. Vigo: Xerais.

Billig, Michael (1995): Banal Nationalism. Londres / California / Nova Dehli: Sage.

Bourdieu, Pierre (2000): Las reglas del arte. Génesis y estructura del campo literario. Madrid: Anagrama.

Bowers, Maggie Ann (2004): Magic(al) Realism. Londres: Routledge.

Casas, Arturo (2009): "Entre Weimar e Albany. Programa e procesos de Torrente Ballester como historiador da literatura", La Tabla Redonda: Anuario de Estudios Torrentinos 7, pp. 13-32.

Colmeiro, Jose F. (2004): "Historia y metaficción en La muerte del Decano de Torrente Ballester. Crónica postmoderna de una muerte anunciada", La Tabla Redonda: Anuario de Estudios Torrentinos 2, pp. $135-150$.

Conde, Alfredo (2003): “Gonzalo Torrente Ballester escritor gallego", La Tabla Redonda: Anuario de Estudios Torrentinos 1, pp. 15-22.

Cuba López, Soledad (2017): Mitos atlánticos en los mundos de Torrente Ballester. Tese de doutoramento. Vigo: Universidade de Vigo.

Durix, Jean-Pierre (1998): Mimesis, Genres and Post-Colonial Discourse: Deconstructing Magic Realism. Londres: MacMillan.

Even-Zohar, Itamar (1990): “Polysystem Studies”, Poetics Today 11/1, pp. 7-94, http://www.tau.ac.i1/ i itamarez/works/books/ez-pss1990.pdf.

Freixanes, Víctor F. (2003): "A cidade literaria (Notas para unha conferencia. 30 años da edición de $L a$ sagalfuga de J. B.)", La Tabla Redonda: Anuario de Estudios Torrentinos 1, pp. 23-34.

Frye, Northrop (1997): Anatomía de la crítica (trad. Edison Simons). Caracas: Monte Ávila.

García, Carlos Javier (2011): "Espacios de control y resistencia en La saga/fuga de J. B.”, La Tabla Redonda: anuario de Estudios Torrentinos 9, pp. 99-116.

Gellner, Ernest (2001): Naciones y nacionalismo (trad. Javier Seto). Madrid: Alianza.

González-Millán, Xoán (1994): Literatura e sociedade en Galicia (1975-1990). Vigo: Xerais.

(1996): A narrativa galega actual (1975-1984). Unha historia social. Vigo: Xerais.

González Echevarría, Roberto (2004): Alejo Carpentier: el peregrino en su patria. Madrid: Gredos.

Guyard, Emilie (2014): “Introducción”, La Tabla Redonda: anuario de Estudios Torrentinos 12, pp. I-IV.

Hobsbawm, E. J. (2000): “Introduction: Inventing Traditions", en E. J. Hobsbawm e T. Ranger (eds.), The Invention of Tradition. Cambridge: Cambridge U. P., pp. 1-14.

Hroch, Miroslav (1991): "From National Movement to the Fully-formed Nation: The Nation-building Process in Europe", en Gopal Balakrishnan (ed.), Mapping the nation. Londres: Verso, pp. 78-97.

Hutcheon, Linda (1995): The Politics of the Postmodernism. Nova York: Routledge. 
(2004): The Poetics of the Postmodernism. Nova York: Routledge.

Jameson, Fredric (1993): “A literatura do terceiro mundo na era do capitalismo multinacional” (trad. María Otero Rodríguez), A Trabe de Ouro 13, pp. 11-30.

Jiménez Heffernan, Julián (2004): "Literatura en España (1939-2000)", en E. Wischer (ed.), Historia de la literatura. Vol. 6. El mundo moderno: 1914 hasta nuestros días. Madrid: Akal, pp. 426-505.

Kohut, Karl (ed.) (1997): La invención del pasado: la novela histórica en el marco de la posmodernidad. Madrid: Iberoamericana.

Loureiro, Ángel G. (2010): “JJavier Mariño falangista?”, La Tabla Redonda: Anuario de Estudios Torrentinos Extra 1, pp. 103-124.

Martínez Jr., Michael L. (2018): Beyond Borders: Gonzalo Torrente Ballester, La saga/fuga de J. B. and the Construction of Literary Fields. Tese de doutoramento. Lubock: Texas Tech University.

Monteagudo, Henrique (1999): Historia social da lingua galega. Vigo: Editorial Galaxia.

Pérez Gutiérrez, Amparo (2005): "Estructura y tiempo en La isla de los jacintos cortados", La Tabla Redonda: Anuario de Estudios Torrentinos 3, pp. 1-16.

Pérez, Janet (2010): “Gonzalo Torrente Ballester, precursor de la «nueva novela histórica»”, La Tabla Redonda: Anuario de Estudios Torrentinos Extra 1, pp. 175-187.

Pólaková, Dora (2016): "La herencia cervantina en La saga/fuga de J. B. de Torrente Ballester", Revista Letral 17, pp. 56-68.

Ponte Far, José Antonio (2019): "La saga/fuga de J. B., epopeya de Galicia”, La Voz de Galicia (edición dixital) 27/01/2019, https:/www.lavozdegalicia.es/noticia/cultura/2019/01/27/sagafuga-jb-epopeya-galicia/ 0003 201901G27P37991.htm [28/04/2019].

Renales Cortés, Juan (1996): Celtismo y literatura gallega. La obra de Benito Vicetto y su entorno literario. Santiago de Compostela: Xunta de Galicia, 2 vols.

Ridruejo, Dionisio (1997): Sombras y bultos. Destino: Barcelona.

Samartim, Roberto (2010): O processo de construçom do sistema literário galego entre o franquismo e a transiçom (1974-1978). Margens, Relaçons, estrutura e Estratégias de planificaçom cultural. Tese de doutoramento. Santiago de Compostela: Universidade de Santiago de Compostela.

Sevilla Vallejo, Santiago (2011): "Progresión y repetición cíclica en la historia de Castroforte del Baralla", La Tabla Redonda: anuario de Estudios Torrentinos 9, pp. 39-52.

Soldevila Durante, Ignacio (1982): Historia de la literatura española actual II. La novela desde 1936. Madrid: Alhambra.

Torrente Ballester, Gonzalo (1981): "Prólogo”, en C. Casares, Ilustrísima. Barcelona: Luis de Caralt Editor, pp. 9-16.

_ (1983): La saga/fuga de J. B. Barcelona: Destino.

(1987): Cuadernos de La Romana. Barcelona: Destino.

(1989): Santiago de Rosalía de Castro. Barcelona: Planeta.

(2009): Escritos de teoría y crítica teatral (ed. José Antonio Pérez Bowie). Vigo: Academia del Hispanismo.

Urza, Carmelo (1991): “El contexto histórico-mítico de La saga/fuga de J.B.”, Hispanófila 102, pp. 57-76.

Valls, Fernando (2017): "Carlos Casares nos outros sistemas literarios españois”, Boletín da Real Academia Galega 378, pp. 367-392.

Vilavedra, Dolores (2000): Sobre narrativa galega contemporánea. Vigo: Galaxia.

Villanueva, Darío (1996): O realismo marabilloso de Álvaro Cunqueiro. Santiago de Compostela: Fundación Alfredo Brañas.

Villanueva Gesteira, María Dolores (2015): A editorial Galaxia: proxecto e traxectoria (1950-1963). Tese de doutoramento. Santiago de Compostela: Universidade de Santiago de Compostela.

Warnes, Christopher (2009): Magical Realism and the Postcolonial Novel. Between Faith and Irreverence. Londres: Palgrave Macmillan.

White, Hayden (1992): Metahistoria. La imaginación histórica en la Europa del siglo XIX (trad. Stella Mastrangelo). México, D. F.: Fondo de Cultura Económica. 